SVETLANA ORIEKHOVA, Mariupol State University (Mariupol, Ukraine)

e-mail: sv.orehova@ukr.net, OCRID0000-0001-9303-4469

\title{
UKRAINIAN POSTAGE AT THE TIME OF THE LIBERATION STRUGGLES IN 1918-1920: HISTORICAL NARRATIVE OF NATIONAL STAMP PUBLISHING
}

\begin{abstract}
The article is dedicated to the reconstruction of national historical narratives in light of national stamp publishing. The research is based on the study of the pictorial aspect of the postage stamps of the Ukrainian People's Republic in 1918-1920 as an expression of state policy towards the development of the national postal service that played an important role in the process of statebuilding. The diachronic analysis method gives an opportunity to study the process of transformation of postage stamps from the philatelic material to the state of cultural and historical monument. Analytical study of catalogued postage stamps with the general narrative of the past state postal structure of the Ukrainian People's Republic is defined as the Ukrainian philatelic heritage. Postage stamps as an element of the statehood of Ukraine in the first half of the twentieth century formed the basis of modern national stamp publishing in contemporary narrative of historical memory.
\end{abstract}

Keywords: historical memory; stamp publishing; narrative; postage stamp; provisionals; philatelic heritage.

\section{Introduction}

The Ukrainian postage stamp has come a difficult way of development for more than a hundred years of its existence, every state formation and its ideological and political preferences left bright and light, as well as sad and sometimes nonsensical prints in its chronicle. It makes sense because the postage stamp is full of information, it is a marker of events, it captures and prints them on pages of historical and cultural memory. After all, the postage stamp is not only a payment for services, but also a miniature thing which has become a symbol of state identification, a sign of the postage payment of the issuing state, a collectible item. Its history is the subject of research that attracts the attention of historians, art experts, cultural scientists and philosophers, which demonstrates the multivectorness of the subject field in scientific discourse.

Famous philatelist and stamp researcher Josip Levitas (1991: 304) believed that the wonderful world of the postage stamp reflects the whole life of humanity, its history, present, environment, achievements of science, culture and art. The postal miniature is "a calling card of the country, worthy of representing it before the whole world" (1991: 3). The pictorial content of the postage stamp provides the opportunity to perceive information which plays an important role in the scientific and cognitive process of statebuilding activity, represents political and economic documents that record the socio-economic and cultural life of the state in a specific way. Accordingly, the history of the postage stamp appears as a narrative of the visualization of Ukrainian history and culture.

Research on questions of technological, socio-economic, political and cultural load of postage stamps of Ukraine of 1918-1920 began abroad in the last century, and domestic philatelists and scientists were able to join the work with this range of problems after Ukraine gained independence.

Thus, the history of Ukrainian philately (1918-1920), the characteristics and peculiarities of its formation, the nature and forms of expression of this phenomenon were developed by the scientist and philatelist R. Byshkevych (2004: 224). Thanks to Roman Byshkevych's research, foreign philatelist-researchers of Ukrainian philatelic heritage were introduced in the scientific circles for the first time.

Analysing the study of the problem of introduction of Ukrainian postage stamps, it should be noted that the philatelic fascination with the postal issues of the young Ukrainian state arose almost at the day of their introduction in the postal circulation. Despite the consequences of World War I, military and political troubles, memorable (commemorative ${ }^{1}$ ) postage stamps became the subject of collecting and studying by philatelic-research professionals. . It is evidenced in some own publications of the collectors of postal products of the UNR: A. Arnold ("Aufdruck-Tabelle de Ukraine-Provisorien" - "Table of overprints on Ukrainian provisionals"2, Berlin-Wilmersdorf, 1919, with time researchers of overprints introduced the name "Arnold's type"); O. Peters ("Ukraine-Falshungen" - "Falsifications of "Ukraine"3 , Chemnitz, 1919); K. Hennig ("The postage stamps of the Ukraine", Berlin, 1919); A. Dornburg ("Ukraine-Aufdruckmarken" - "Ukrainian Reprints", Vienna, 1919); G. Burgess ("The Tridents of Ukraine. An Exhaustive Reference List", London, 1919) (Бишкевич, 2004: 45). From 1919 to 2005 in Germany, the Ukrainian Philatelist

\footnotetext{
${ }^{1}$ See: commemorative stamp (comme - like that, memoria - memory - from French) - generalizing name for artistic special (memorable, anniversary and other) postage stamps.

2 See: an overprint in the form of a trident (coat of arms of Ukraine) on postage stamps of the Russian Empire made by postal districts under the order of the Administration of the Ukrainian State of August 20, 1918.

${ }^{3}$ Falsifications of Ukrainian stamps of the 1918 Civil War in southern Ukraine.
} 
Union ("Ukraine-Philatelisten Verband") (in further text UPU) functioned; well-known philatelists: Alvin Arnold, Karl Engels, Henry Keller, Arnold Meyer, Oscar Erich Peters, K. Henning (1920: 72), Rudolf Seichter (1942: 36; 1966: 70 ) and other researchers who not only participated in the activities of the UPU, but devoted their entire lives to the systematic collection and study of postal-historical and postal-technological characteristics of Ukrainian postmarks were among the expert members.

Intelligence of the members of the "Ukrainian Philatelic and Numismatic Society"4 (USA): E. Kotyk, S. Kikta, S. Roberts (1989: 176), L. Gugel (1988: 36), I. Kuzich (2004: 50) and other researchers of these problems are full of reference sources, descriptive, informative and illustrative materials that enrich the history of national philately.

The prominent Ukrainian philatelist and expert Ivan Bulat carefully collected and studied issues of postage stamps of the UNR and ZUNR. His fundamental researches were published in the USA: "Illustrated History of Postage Stamps of the West Ukrainian People's Republic of 1918-1919" (1973 during his lifetime) (1973: 96); "Comprehensive Catalogue of Ukrainian Philately" after his death with the support of the author's friends and family (2003: 301).

Ukrainian public and cultural-educational figure Yevhen Vyrovyi, known as one of the most recognized specialists in the philatelic world, collected Ukrainian stamps, exhibited his collections at international philatelic exhibitions, and his collections received international awards. Y. Vyrovyi's articles in the "Ukrainian Philatelist" - "Postage stamps of the Ukrainian People's Republic" (1925 p.), "Trident" (1926 p.) - are thorough researches on the history of the origin and introduction of the Ukrainian stamp. As O. Redko (2017: 187-188), noted, Y. Vyrovyi can certainly be considered the founder of philatelic Ukrainics.

A formation of historiography of this problem during the period of independence was conditioned by the general explosion of interest in the history of Ukraine and regional study. Significant contribution to this case was made by native philatelic researchers: A. Brandelis, V. Martyniuk (2003: 10-12), V. Mohylnyi, V. Bekhtir (1997: 176) and others. Since the 1990s, professional journals (magazines, bulletins, newspapers) have been published, on the pages of which the works of foreign Ukrainian studies researches-philatelists, in particular, representatives of the Ukrainian diaspora, such as Y. Maksymchuk (1996: 2), A. Chyhryntsia (1994: 18-23), S. Shramchenko (1996: 10-12) are published.

The philatelic catalogues-directories of collectable materials, authored by M. Kramarenko (2011: 336), I. Hontsaryuk and D. Rypela (2017: 416), present systematic, comprehensive information (production, philatelic featu- res, information about varieties, issues, cost etc.) about the artistic and standard stamps of Ukraine, which essentially supplements the vision of the state of the research of the chosen topic. Thus, the national historiography returns to its own national history and its national achievements in stamp publishing.

The purpose of the proposed research is to reconstruct the historical narrative of national stamp publishing through the visual component of the postage stamp through which we look at past historical reality.

\section{Methods of the research}

The subject field of the research determines its multidisciplinary nature, which causes appealing to adequate research methods. A comprehensive approach to covering the complex spectrum of issues of postage stamping of 1918-1920 required the use of art study methods (analysis of genre and artistic content of stamps bearer of historical information), historical and cultural methods - to distinguish entire "images-plots" of postage stamps that reflect Ukrainian culture in Ukrainian history; diachronic - in the study of the process of transformation of postage stamps from philatelic material to the cultural and historical heritage; analytical - when studying historical, cultural literature and when working with sources on the topic of research.

\section{Results and discussion}

The Ukrainian school of stamp printing was established during the period of the revolutions of 1917-1920, when the state-building processes became more intensive and more significant. The Central Council of the Ukrainian People's Republic granted the status of state language to the Ukrainian language, developed and adopted state symbols (national anthem, flag, coat of arms), created its own monetary system, which included postage stamps.

Although the first Ukrainian postage stamps appeared in the world philatelic space in 1918, they certainly fit the profile of postal issues of the classical period (Grallert, Grushke, 1977: 65), because they were introduced in postal circulation for technological, technical and organizational support and arrangement of postal business in Ukraine. Postage stamps of the UNR issue of July 18, 1918 (drawings of "stamps-money" of the issue of May 27, 1918 were used for the issue of postage stamps) had original artistic images of exclusively national symbols of a high artistic level: trident - national coat of arms - and ornaments (stamps of 10, 40 and 50 shahs), allegorical images of a Ukrainian peasant worker (20 shahs) and a girl in a wreath of wildflowers and ears of wheat as a symbol of Ukraine's revival (30 shahs) (Kramarenko, 2011: 52) (see fig. 1).

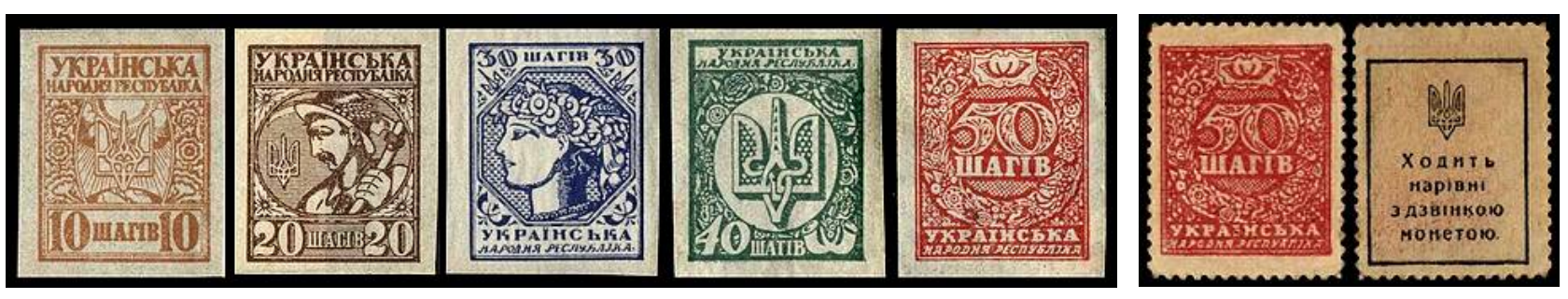

fig. 1. Postage stumps-"shahivky" (on the right) and money-stamps (on the left) of the Ukrainian People's Republic of 1918

\footnotetext{
${ }_{4}^{4}$ Interest of Union includes postage stamps of the Ukrainian People's Republic (1918-1920), West Ukrainian People's Republic, Transcarpathian Ukraine and occupation administrations. At the same time, the last philatelists of the Union include Ukrainian issues of all states and military administrations that existed in the territory of modern Ukraine.
} 
Named "shahivky", these stamps were used in the postal circulation for the following technological operations: 1) payment for the sending of written correspondence (postcards, letters, parcels, among them are simple, recommended, valuable, packages with cash on delivery, requests for summons); 2) covering address postal forms for parcels (simple, recommended, valuable, with cash on delivery); 3) covering address postal forms for money transfers sent by post and telegraph; 4) payment of applications related to the readdress, return, delay of the postal items and postal mailing certificates; 5) payment for the transmission and delivery of telegrams (simple and urgent) ${ }^{5}$. Stamps-"shahivky" were in circulation officially in 1918 and were liquidated as a means of payment by the Soviet authorities, but their use in the postal business in Ukraine continued until $1920^{6}$.

The issue of five banknotes of low denomination of May 27, 1918 was due to the lack of a coin, they functioned as paper money and were called "money-stamps" (see fig. 1). Money-stamps were printed in big pieces of paper, a trident and a text "Goes on equal terms with the coin" confirming its legitimacy were printed on the back of each banknote. It was not allowed to use them as postage stamps, but cases of use them as payment for postal correspondence and philatelic mails were known (Bekhtir, 1997: 138). The question of introducing and distributing "shahivky" stamps and "money-stamps" of the UNR on the territory of Ukraine was covered by V. Furman (2003: 224).

According to R. Byshkevych (2004: 33) regarding the estimation of masterful performance of stamps, "the first UNR stamps - "shahivky" - were unusual phenomenon, they do not cease to arouse admiration of specialists with the richness of artistic content and the genius simplicity and laconism of their performance at the same time, combining a strict line of drawing and classical means of composition". Therefore, it is natural that ideally they corresponded to the postage stamps of the United Kingdom and Europe that were introduced in the postal circulation since the 40's of the XIX century, which shows the authors' adherence to many years of experience and certain canons of publishing. For example, the drawing of the 30-shah stamp "Young Ukraine" according to V. Furman (Furman, 2003: 15) is "textbook", the girl's profile resembles to the UK postage stamp "black penny". It is also symbolic that the plot of the first standard issue of independent Ukraine (6 denominations, karbovantsi, 1992) reconstructed the thematic line of Heorhiy Narbut's drawing (see fig. 2)
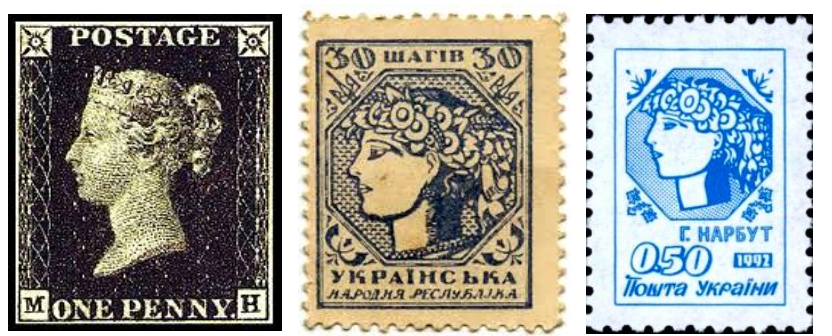

fig. 2. Postage stamps: "Black penny"

(on the left - Great Britain, 1840) and "Young Ukraine"

(in the middle - Ukrainian People's Republic, 1918,

on the right - the first standard issue "Young Ukraine", Ukraine, 1992.)

\footnotetext{
5 State Archives of Donetsk Oblast (further - DADO), f. F.-80, d. 1, case. 1686 , p.140-142.

6 DADO, f. F.-80, d. 1, case. 13, p.138-139.
}

The awesomeness of introducing shahivky lies in the extraordinary abilities of the people, their desire for the creation of their own state, the ability to create national channels of postal communication under cramped conditions, to make functional use of their own postal products with a characterological cultural state identification. The authors of the stamps were such prominent Ukrainian graphic artists: H. Narbut, A. Sereda, L. Oboznenko, I. Mozalevskyy and others (Kramarenko, 2011: 52). The talented graphic artist Heorhiy Narbut and his student Anton Sereda created postage stamps that had not only postal and bank, but also artistic value, and today they constitute the philatelic heritage of Ukraine. As V. Furman noted, "H. Narbut did not blindly copy the classic profile of Queen Victoria, replacing the imperial crown (symbol of monarchical power) with a wreath (traditional national maiden dress), he created a truly national image a symbol of Ukrainian spring, the embodiment of feminine origin in a young country" (Furman, 2003: 15). Stamps of UNR issued in 1918 are catalogued and presented in famous European $^{7}$ and Ukrainian postage stamp catalogues ${ }^{8}$.

The State Archive Services of Ukraine preserve shahivky stamps in their funds in sheets, single, on postal items, but this is a drop in the ocean. A significant amount of philatelic material is stored in foreign private collections of philatelic Ukrainianists, who managed to remove and thereby save from the total destruction the postal material of the UNR authorities. According to the postage stamps catalogue of Ukraine by $\mathrm{V}$. Hontsariuk the total circulation of five issues was 117,3 million units of stamps (Hontsaryuk, Rypela, 2017: 6). According to the author, it should be assumed that $10 \%$ of the circulation was involved in the production process, payment for written correspondence, money transfers, philatelic mailings; $15-20 \%$ were in cash circulation; $10-15 \%$ were sold as philatelic products; $10 \%$ were removed by collectors during the evacuation of the UNR government, so, near $45-50 \%$ of the circulation was destroyed. The reasons are more than clear: the struggle against the ideology of the bourgeois system which began actively after the evacuation of the UNR government and continued in the following decades. The first wave of physical destruction occurred in 1923, operational postal materials were eliminated as waste paper of the canceled Ministry of Posts and Telegraphs of the UNR, and postage stamps were destroyed in connection with the "task of forming new, progressive ideological foundations of philately" (Levítas, Basyuk, 1975: 31 ); the second wave (1932) was more persistent and captious, the main idea of it was active introduction of the ideological preference of the Soviet Socialist system, archival and museum funds, which somehow resembled or belonged to the UNR, were destroyed. Thus, the catalogue of original author's drawings of postage and fiscal stamps by H. Narbut, M. Boiarchuk, H. Zolotov, O. Krasovskyi, I. Mozalevskyy, L. Oboznenko, A. Prykhodko, B. Romanskyi, L. Rozov, I. Rumiantsev, M. Salnykov, and A. Sereda was destroyed (Bilokin, 1996: 19). The fate of the catalogue is too dramatic, Roman Byshkevych (2004: 35) reveals the history of the catalogue in more detail: how it was removed during the evacuation of the UNR govern-

\footnotetext{
${ }^{7}$ See: Senf Gebrüder. 1930. Ukraine-Katalog. Sonder abdruck der bischer. Ukraine-Bearbeitung im Gebr. Senf's Europa-Katalog mit der neuen Aufdruck-Typen-Tafel als Einlage ergänzt u. Bearbeitet nach den Richtlinien des U.P.V. Leipzig: Gebrüder Senf in Leipzig. ${ }^{8}$ Catalogue of postage stamps of Ukraine. 1997. Куіv. Каталог знаків поштової оплати України. 1997 р. Київ: Ukrainian Postal Service "Ukrposhta", publisher "Stamp of Ukraine".
} 
ment, restored after damage from water, during a break of the water supply system in the winter of 1926 , in a place where it was temporarily stored in Tarnów (Poland); as in February $1928 \mathrm{H}$. Narbut's pupil Pavlo Kovzhun conveyed it as a deposit to the Museum of the Scientific Society n.a. Shevchenko in Lviv; as in 1932 the catalog was exhibited for the first and only time at an art exhibition of the Association of Independent Ukrainian Artists. Unfortunately, neither the merits of $\mathrm{H}$. Narbut (author of many works of national importance: head ornament for the first edition of the Constitution of the Russian Socialist Federal Soviet Republic in 1918, the design of magazines "Art", "Sun of Labor", "People's Economy of Ukraine", (1919-1920), "Ukrainian Alphabet" (1917, 1919), paper money, including banknotes of 250 karbovantsiv (1918), etc.), nor the merits of other Ukrainian graphic artists before the Soviet authorities were able to save the most valuable material of the classical period of Ukrainian philately and primary sources of Ukrainian school of stamp making.

Today, in accordance with paragraph 2 of Art. 17 of Section III of the Law of Ukraine "On the National Archive Fund and Archives", the state is working on accounting, returning of documents of historical and cultural heritage of Ukraine that are abroad and documents of foreign origin concerning the history of Ukraine ("Archival Ukrainics") So, there is an information on the official web-portal of the State Archival Service of Ukraine in the section "Archival Ukrainics" that 24 units collection stamps of UNR were returned from France, the Russian Federation for the period of 1993-2015.

Shahivky stamps were not the only postal products used to support the UNR postal communications (from April 29, 1918 to December 14, 1918, the Ukrainian state). Thus, there were significant remains ${ }^{10}$ of Russian postage stamps in technological circulation and in the reserve. It was impossible to replace them simultaneously in all structural units in the postal and telegraph districts of the Ministry of Posts and Telegraphs, and it was necessary to fulfil obligations for potential post users.

The only correct solution to technological problems in the so-called "stamped hunger" of the post was the use of stamps of the Russian Empire with the printing of an overprint on it (provisional) ${ }^{11}$. According to the order of August 1918 (Bekhtir, 1997: 138) the State Emblem of Ukraine - "trident" postage stamps had to be applied in such a way to close the two-headed Russian eagle. This solution made it possible to solve complex administrative problems: firstly, technological - to continue to provide postal and telegraph services; secondly, economic - to prevent excessive use of the postal products (since September 1, 1918, postage stamps of the Russian Empire without an overprinted trident were considered invalid). In addition, this decision embodied the foreign policy and national-political principles on which Ukraine positioned its political subjectivity.

The initial experience of constructing the logical concepts of the introduction and systematization of Ukrainian provisionals in 1918 was marked by the works of I. Bulat, R. Seichter, A. Arnold (separately investigated issuesforgeries), F. Chuchin and others.

\footnotetext{
9 Laws of Ukraine, 1994.

10 See: the remainder of the postage stamps per post office depended on the amount of the postal items for a period of three months.

11 Provisional - ("provisoire" temporary - from French) temporary valuable postal matter that is issued by state government, local authorities.
}

The overprinting of stamps, namely the introduction in the postal circulation of the provisionals, was entrusted to the governorate postal and telegraph offices in four posttelegraphic districts operating in Ukraine at that time: Kyiv (p-t. o.) (Kyiv, Volyn, and Chernihiv provinces), Kharkiv (p-t. o.) (Kharkiv province), Katerynoslav ( $p$-t. o.) (Katerynoslav and Poltava province), Odessa (p-t. o.) (Kherson province) and Management of Podilsk postal and telegraph institutions (Podilsk province). Provisionals were made by both high and lithographic printing in printing houses and by hand stamps using available technical means (made of metal, rubber or wood) (see fig. 3 ). This resulted in wide variety of types and graphic performance of overprintings. Depending on the means of manufacturing and drawing the trident, researcher M. Kramarenko catalogued 6 types of provisionals, 39 types of them were variants of images of the trident and 1917 were varieties (Kramarenko, 2011: 97-101).
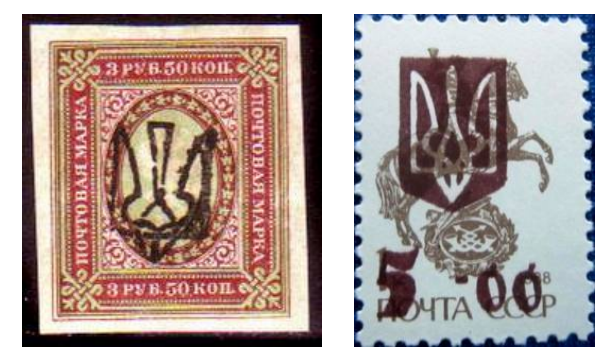

fig. 3. Provisionals of the Ukrainian State - overprint of the coat of arms "trident" postage stamps:

(on the left - the Russian Empire, 1918); (on the right - the USSR, 1992)

Thus, the provisionals of the Ukrainian government were made on the Russian Empire stamps: a) postage in 23 denominations (41 types in general: imperforated and perforated, different denominations and years of issue); b) savings - in 3 denominations (1, 5, 10 kopecks); in addition, the first postage stamps of the RSFSR "Hand with a sword cutting the chain" - in 2 denominations (35, 70 kopecks, issue of November 7, 1918). The campaign to the overprinting of Ukrainian coat of arms on Russian stamps was officially completed in September, and from October 1, 1918 on the territories under the authority of the Ukrainian State only "shahivky" stamps and provisionals were legitimate in the postal business. By the way, the history of Ukrainian postage also included provisionals of 1992. During the establishment of the postal service of the independent state, the coat of arms of Ukraine was marked on the postage stamps of the USSR (Order of March 25, 1992 No. 52 of the State Committee of Ukraine for Communications "On introduction in circulation of standard stamps with an overprint") (Bekhtir, 1997: 140).

The issue of the standard postage stamps of the UNR in 1920, the so-called "Viennese issue", had a completely different fate. The technological-postal life cycle of this issue was too short (almost half a year, five months of which were design and printing works), but it was important in preserving the past, forming the historical memory, historical-cultural and philatelic heritage of Ukraine.

Before turning to the description of the structural elements of stamps, let us turn to the political events of the time that directly influenced and formed the activity of the postal service as the only accessible, stable, widespread means of communication of the independent state. In conditions of continuous liberation struggles, military events, intervention, economic ruin, every power formation counted on clear and coordinated work of postal and 
telegraph institutions. Firstly, it is the speed of transmission and delivery of messages, the connection between the center and the provinces; secondly, postal products (postage stamps, stamped postcards and envelopes) are a significant financial component in the system of strengthening the economic stability of the state and an element of the monetary system; thirdly, each postage stamp, its plot corresponds to the ideological integrity and political orientation of the state system; fourthly, to some extent, post was/is a sign of statehood recognized (or not) by the world community.

Thus, it is logical that the authorities of the UNR obliged the Ministry of Posts and Telegraphs to set a single currency - the equivalent of funds - a postage stamp, which was a financial document and had to be purchased only in the state postal and telegraph offices of the UNR, in the circulation. Advantages of such decision were: firstly, liquidation of stamp disorder and prevention of financial abuses - thefts, forgeries (the first issues of "moneystamps", provisionals, Austrian and Hungarian overprints (ZUNR stamps before 22.01.1919 signing the Act Zluky (Unification Act)) and the main thing - illegal circulation of postage stamps of other authorities (postage stamps with overprint and postage stamps of post offices of the Crimean provincial authorities and the Armed Forces of South Russia were used at the time); secondly, recording the production and sale of postal products, in other words, planning for business activity of the branch, informative value and the ability to respond to the new postal rates which were introduced in June 1920; and thirdly, equally important, is ensuring national interests, such as sovereignty, national identification.

Thus, Stepan Kikta (1980: 3505) calls the event August 26,1920 an event of positive political change as far as the government decided to remove all previous proper and other issues from circulation and change them to new (series of 14 plots with hryvnia denominations), work upon the development of which had been conducted since the end of 1919 at the printing house of the Military Geographical Institute in Vienna (Austria), hence the name "Viennese issue". Denominations of stamps from 1 to 200 hryvnias, drawings of eight of these stamps and the whole design of the series were made by Mykola Ivasyuk, one of the foremost realistic artists of Ukraine of the early twentieth century, the image on other stamps was made on the basis of the official graphic design of a trident, portraits of T. Shevchenko, B. Khmelnytsky, I. Mazepa, $\mathrm{S}$. Petliura and photographs of historical objects (Bekhtir, 1997: 138).

The history of existence of the Viennese series, without exaggeration, is the most interesting and sad at the same time. The series had several functions - state, postage, cultural. We will try to outline in a thesis form the general motives of the historical conditions of the rise, fall and revival of Ukrainian picturesque stamps - the "Viennese issue".

The first thesis - renewal. There were many hopes and preconditions for introducing own postal stamped products, which was subjectified in appropriate cultural form - postal miniature, by the way, of international standard. In author's opinion, the decision to place a print order in an institution that had worldwide experience in printing of color geographical maps, which meant the accuracy of engraving, small details, color, degree of protection, is completely explained.

The second thesis - national dignity. The architecture of each stamp is saturated with elements of traditional national symbols: names, fonts, characteristic figures Cossacks, Chumaks, girls in national dressing, huts, wheat fields, blue skies. Each plotline describes how history and memory contributed to the formation of characterological cultural state identification.

The third thesis - state postage signs. Approved and printed, they did not become postage signs, they were not fated to be in the postal circulation. Such paradoxical situation is possible at the turning point of political convictions. The regulations of the Universal Postal Union (UPU) and the world community adopted the essential features that characterize the postage stamp as follows: a) used for mailing postal items by sticking; b) has a value (monetary value) that determines its franking power; c) has the name of the emitent country; d) in the technological process it is envisaged to place a postmark of the post office over a stamp in order to avoid reuse; e) has elements of protection against forgery; e) the emitent country of the postage stamps must be a member of the UPU; g) the emitent country must have unlimited postal sovereignty throughout the territory; $h$ ) the stamps publisher must have its own post offices and the necessary means of transport to provide the mailing and delivery of postal items (Grallert, Grushke, 1977: 90). Viennese issue stamps had all these features, so they undoubtedly had all the features of state postage stamps in their classic work.

In October 1920, political circumstances radically changed the further "postal life" of the issue. Due to the evacuation of the UNR government and the loss of statehood newly printed postage stamps lost their meaning. In order to preserve the legitimacy of the issue, the head of commission for stamp producing P. Soroko and members of the commission issued an official document confirming their government status, and on March 11, 1921 the signatures of the UNR government representatives were legally authenticated by the Consular Department of the Embassy of the UNR in Austria (Furman, 2005: 6). By this act, postage stamps received the opportunity to be distributed as a philatelic material of the UNR, which in fact saved their physical life outside their homeland.

Therefore, due to the loss of statehood of the emitent of the UNR state postage signs became non-postage stamps. In the philatelic world, this type of stamps has a fairy-tale name - cinderella (Bekhtir, 1997: 137).

The fourth thesis - ideology and politics. The series was banned for: storage as archival material; historical research, even for the research of activities of the postal service; collecting by Ukrainian philatelist and Ukrainian studies researches, and series was not mentioned at all in the Soviet philately, or named as "the old rubbish and legacy of the hated bourgeois-nationalist system" (Byshkevych, 2004: 33).

The fifth thesis - revival and relevance. Forgotten for years, abandoned "in the attic of history", today the postage stamps of 1920 are an insufficiently studied pictorial source of a special historical discipline - "philately". Modern researchers, and the vast majority of them are collectors, only return to the theme of "Viennese issue". The difficulties faced by researchers are the limited amount of archival material in Ukraine. Literature on Ukrainian philatelic themes, in particular the magazines "Ukrainian Philatelist" (published from 1925 to 1939 in Vienna), monographs, catalogues, collections, were almost completely destroyed (by political ideologies of governments, wars). But both the "manuscripts do not burn" and the collections "rise from the ashes". Thus, in the funds of the Central State 
Archives of Supreme Authorities and Governments of Ukraine, samples of the Viennese issue stamps of only five denominations: $1,2,3,5,10 \mathrm{hrn}^{12}$, as well as a printed copy of the "UNR Postage Stamp Patterns catalogue" (1931), which provides a description of the full issue ${ }^{13}$, are stored.

And the originals of printed sheets with stamps can be found in the Vienna archives and in private collections exhibited on the stands of international philatelic exhibitions.

The sixth thesis - historical and cultural heritage. The Ukrainian issues of 1918-1920 are a wonderful and interesting part of philately for collectors and historians, they contain information for comprehensive scientific research as pictorial sources. Not only types of images (coat of arms, ornaments, inscriptions), but also dates, denomination numbers and the designation of the state currency are bearers of historical information. An interest in the historical past stimulates the process of reviving of historical memory.

Therefore, the named above tendencies of the historical, political, technological, cultural life of the postal issue are developed into a comprehensive study of all elements of postage stamps, which allows to establish the place and time, causes and circumstances of their functioning, thereby reconstructing the historical narrative of national postage stamp producing.

In December 2020, the Viennese issue of UNR postage stamps will celebrate its 100th anniversary. The phenomenon of these stamps is still not fully researched. On the one hand, they can be classified as printed products, which nearly fell into the waste paper due to refusal in receiving by the customer, and, on the other, underestimation of the cultural significance of the plot conceptual importance and historical preconditions for the introduction is, at least, a crime relative to historical memory.

Despite the fact that they have never been in the postal circulation, what means that they did not fulfil their most important function, today they perform a great historical and cultural functions. They still are the best in reconstructing Ukrainian national character. Fourteen plots of stamps depict the symbols of the new independent state: the coat of arms - trident, the blue-yellow flag, the building of Parliament, portraits of several prominent figures who contributed to the establishment of statehood, national musical instruments, scenes from the Cossack times that promote the upbringing of Ukrainians' love for liberty, scenes of rural life typical for early twentieth century of Ukraine. To emphasize national character, each stamp has traditional folk elements: decor, embroidery or weaving patterns. The total circulation of the series was 120.0 million copies (see fig. 4).

The drawings of all stamps except plots of 1 and 60 hryvnia denominations consisted of two separate parts: a frame and a vignette (the central part of the figure). The reason for this separation was the possibility of using the same frame for different denominations, replacing only the vignette and the denomination number. Thus, three frames were used many times. The designs for the 3 and 5 hryvnia stamps were the same, and the same for the 15 and 20 hryvnia stamps. Also the main frame was used for plots of denominations of 2, 10, 30 and 50 hryvnias, but it was slightly modified to match different designs of vignettes. The designation of approval of current design, as well as the date of approval and signature of the former director of the Kyiv Post and Telegraph District and P. Soroka, secretary of the commission I. Shmatko and M. Sekretar were on the back of most vignettes (Furman, 2005: 6).

It is undeniable that the postal miniature contains pictorial components, the artistic level of which constitutes an aesthetic origin. Therefore, attention should be paid to the depiction of postage stamps on the historical, cultural and aesthetic criteria.
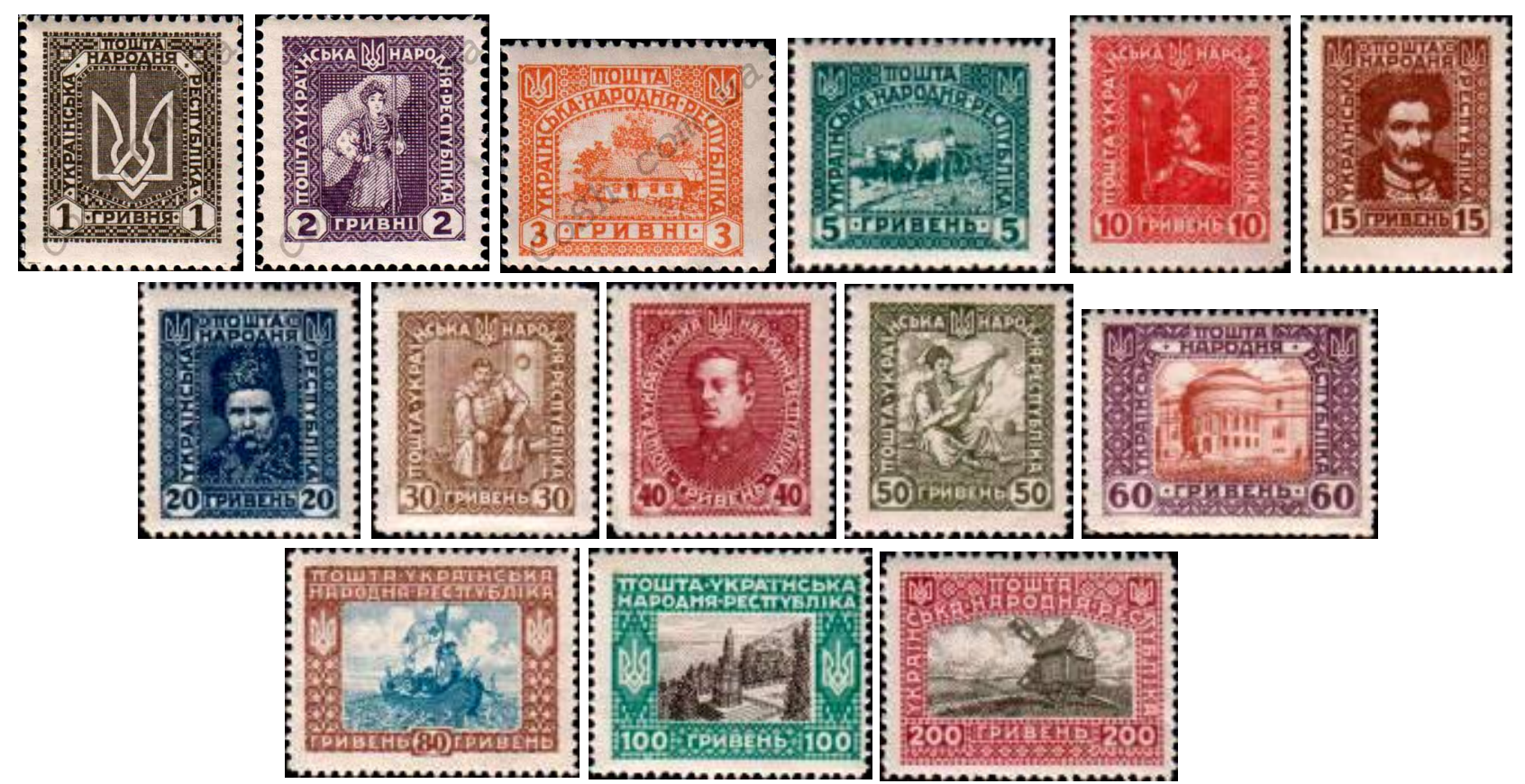

fig. 4. Postage stamps "Viennese issue", 1920

\footnotetext{
12 The Central State Archives of Supreme authorities and governments of Ukraine (further -CSASA), f. 4018, d.1, case 93, p. 1 ${ }^{13}$ CSASA, f.4465, d. 1 , case 35 .
} 
The first stamp had a face value of 1 hryvnia, from dark gray to olive color, size of circulation was 2 million copies. In the center of the image is a large trident - a symbol of Ukraine, around of it is the ornament of Ukrainian embroidery. This design, like the 60 hryvnia stamps, were the only ones made as a whole. All other designs were combined from individual vignettes and frames. The trident as a heraldic sign is present in all plots, it is an obligatory element of the emitent country.

Stamp with a face value of 2 hryvni, dark purple, violet, circulation was 4 million copies. On the vignette is an allegorical image of Ukraine in form of a young woman in an embroidered dress with a Ukrainian flag in her hands. The flag, adopted at the same time as the trident, has two horizontal stripes: yellow-gold over blue (azure). These two colors today represent the golden fields of wheat under the blue sky. The design of an ornament of the stamp is Ukrainian embroidery. It is the same as on the stamp of 10 hryvnias, except that the inner part of the lower frame of the stamp of 10 hryvnias (above the word ГРИВЕНЬ) was removed to put a slightly larger vignette with a female figure in its place.

The drawing of a stamp of 3 hryvni is a Ukrainian house with a garden, yellow-orange-colored. The drawing of the house was supposed to symbolize the house of Taras Shevchenko, but in some structural details it differs from the sketch of T. Shevchenko made by him from his house. The ornament of the stamp has the pattern of the Ukrainian embroidery, the same as on the 5-hryvnia stamp. Two hexangular figures, with the sign " 3 " on the one side and " 5 " on the other, were used to indicate the numbers in the lower corners of the frame on both 3-hryvnia and 5-hryvnia stamps.

Five hryvnia dark green stamp, 4 million copies. The vignette depicts a chumak with oxen in a yoke - an image of the Ukrainian rural landscape, dating from the seventeenth to the middle of the nineteenth century. Chumaks originated from the caravan trade of the times of Kyivan Rus and exhausted itself with the introduction of railways in the nineteenth century. As an important component of economic life at all historical stages, it had great commercial value, was a symbiosis of trade and transport, an inherent infrastructure of the economy, a unique national phenomenon.

Postage stamps of denominations of $10,15,30,50$, 80 hryvnias cover the theme of Ukrainian Cossacks. The Cossacks became a symbol of statehood and spirituality of the Ukrainian people.

The portrait of Hetman Bohdan Khmelnytsky was reproduced on the red stamp of 10 hryvnias, circulation of 20 million copies. The ornament of the frame consists of a pattern of Ukrainian embroidery, there is some similarity with the frame of the 2-hryvnia stamp. On the vignette of the stamp of 15 hryvnias is an image of Ivan Mazepa. Ornament is Ukrainian cross-stitch. The Ukrainian coat of arms is woven in the upper corners. Stamp color is chestnut, the circulation was 4 million copies.

30-hryvnia, clear-chestnut color, with a circulation of 4 million copies. It respects Pavlo Polubotok as a prisoner of the Peter and Paul casemate. Vignette shows hetman in chains in prison cell. The ornament of the frame consists of a pattern of Ukrainian embroidery, which is similar to that on the denominations of 2 and 10 hryvnias.

The image of the Cossack sitting in the steppe and playing in the bandura symbolizes the times of the emergence and flourishing of Ukrainian Cossacks, the perception and assimilation of its ideology by the people, which is reflected in folk Dumas. This plot is depicted on the stamp of 50 hryvnias, the color is olive green, circulation is 5 million copies.

The next stamp of the series is dedicated to the theme of Cossack glory and reflects the history of the Ukrainian marine forces. The vignette depicts the Zaporozhian Cossacks in "chaikas" in the Black Sea. In the first "chaika" the man is standing and holding the Cossack flag, others men are paddling. And on the horizon there is another "chaika" with raised sails. Denomination of stamp is 80 hryvnias, colors are chestnut and violet, ornament is Ukrainian carpet with woven Ukrainian coats of arms on the sides. The very fact of the issue of such stamp shows that the historical memory of the Ukrainian Cossacks is a decisive aspect in the formation of national character and is an inexhaustible theme for Ukrainian literature, art, including philately.

Stamp of 20 hryvnias is devoted to the memory of Taras Shevchenko, color is steel-blue, printed in circulation size of 20 million copies. The ornament of the stamp repeats the ornamentation of the 16 hryvnia stamp. T. Shevchenko's figure is too famous, therefore shortly, he was one of the founders of classical Ukrainian literature, poet, prose writer, dramaturgist, artist. His works awakened the Ukrainian national consciousness, aimed at national spiritual revival.

The outstanding figure, Symon Petliura. His portrait is depicted on a vignette in the shape of an ellipse (medallion), portraits of monarchs are usually depicted in such a way. The border is made in the style of Ukrainian ornamentation (embroidery patterns). It is possible that the government wanted to emphasize the importance of the figure of the Head of Government of the Ukrainian Directory. The topics of postage stamps often reflects the political (in particular in historical field) preferences of the dominant power. Denomination of stamp is 40 hryvnias, circulation was 20 million copies, wine-colored.

Stamp of 60 hryvnias depicts the building of the "Central Rada" (former Pedagogical Museum) in Kyiv. The frame ornament consists of a Ukrainian woven tapestry. Circulation was 3 million copies, color is chestnut-yellow, made in two colors, as well as in 80, 100 and 200 hryvnias.

Vignette of 100 hryvnia stamp of blackish-green and blue-green color reproduced the monument to St. Vladimir the Great, Baptist of Rus. The figure is turned to the bank of the Dnieper where pagan citizens accepted a christening in 988. The frame ornament consists of a pattern of Ukrainian woven carpet. Circulation of 6 million copies.

The last "Viennese issue" stamp of denomination of 200 hryvnias, olive-gray and light red color, reflects the rural landscape - wheat fields, windmill. Philatelic expert L. Huhel (1988: 36) determined that author M. Ivasiuk created two vignettes for this stamp (variant " $A$ " is simpler and " $\mathrm{B}$ " is more detailed), but the printers used a sketch "A". Why the author treated the drawing so tremblingly? He might have considered it necessary to reproduce all the greatness and beauty of Ukrainian land.

About printing features. The issue stamps were lithographed from zinc plates on 500 printed sheet, arranged in postal sheets of 100 or 50 stamps. The sheets were perforated linearly in size of $11 \frac{1}{2}$ (some denominations were also perforated in $101 / 2$ ), in addition there were stamps without perforation. Printing test was done on paper of various quality, some stamps were printed on geographical maps. Monochrome stamps were printed in sheets of 300 units, which were divided into two hundred stamp pieces and two fifty stamp pieces. Thus, the miniatures of the 10 and 11 lines had a clear stamp field, which means that each sheet of 300 marks contained 20 vertical gutter pairs (Furman, 2005: 7). This variant of stamp place- 
ment is especially valued in the philatelic world, a large median cross is formed between gutter pairs. Sometimes trademarks, emblems, advertising and informative signs or drawings are printed gutter pairs. The method of printing a stamp letter in gutter pairs is a rare type in stamp printing business (see fig. 5).

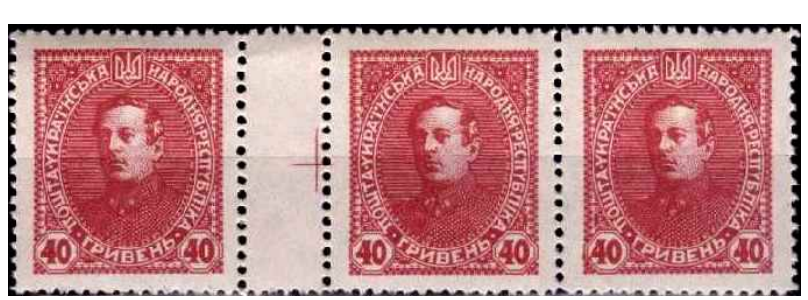

fig. 5. Gutter pairs (on the left - UNR stamps of 1920, on the right - Ukrainian stamps of 2001)

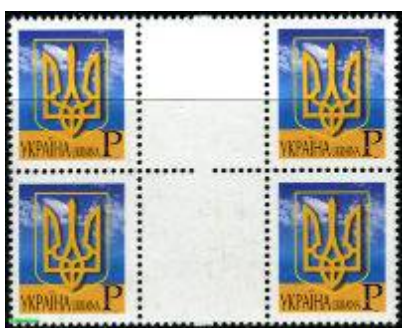

\section{REFERENCES}

Arnold, A. (1919). Aufdruck-Tabelle der Ukraine-Provisorien. Berlin - Wilmersdorf.

Bekhtir, V. (1997). Kataloh poshtovykh marok Ukrayiny. Kyiv: Ukrayinske derzhavne pidpryyemstvo poshtovoho zvyazku "Ukrposhta". (In Ukrainian)

Bilokin, S. (1996). Heorhiy Narbut i ukrayinska poshtova marka. Poshta i filateliya Ukrayiny, No 1: 19. (In Ukrainian)

Bulat, J. (1973). Illustrated Postage Stamp History of Western Ukrainian Republic 1918-1919. Yonkers: Philatelic Publications.

Bulat, J. (2003). Comprehensive Catalogue of Ukrainian Philately. Yonkers: Philatelic Publications.

Byshkevych, R. (2004). Nacherk istoriyi ukrayinskoyi filateliyi. Klasychnyy period. Halfilvisnyk (special issue). (In Ukrainian)

Chinburg, Ziven K. (2015). "Halting the Revolution: Poland and the "Miracle at the Vistula". Constructing the Past: Vol. 16: Iss. 1, Article 4. Retrieved from https://digitalcommons.iwu.edu/ constructing/vol $16 /$ iss $1 / 4$

Chuchin, F. (1927). Katalog pochtovykh marok itselnykh veshchey. Issue IV. Ukraina. Moscow: Sovetskaya filatelisticheskaya assotsiatsiya. (In Russian)

Chyhrynets, A. (1994). Poshtovi marky Ukrayiny. Istoriya, opys, klasyfikatsiya (1948 Bryusseles). Lviv. Halfilvisnyk. Issue 1. (In Ukrainian)

Furman, V. (2003). Obshchegosudarstvennyye standartnyye pochtovyye marki Ukrainy. In: Kiyev: Marka Ukraí ny. (In Russian)

Furman, V. (2005). Pryvablyvosti "Popelyushky". Filateliya Ukrayiny. No 4 (54): 6-8. (In Ukrainian)

Grallert, V., Grushke, V. (1977). Filatelisticheskiy slovar [transl. from german]. Moscow: Sviaz. (In Russian)

Hennig, K. (1920). Ukraine. Weimar.

Hontsaryuk, I., Rypela, D. (2017). Kataloh poshtovykh marok (19182017). Bratislava: DIVARI. (In Ukrainian)

Hugel, L. (1988). Postal Usage of Stamps Issued in Ukrain: 19181919. Ukrainian Philatelic and Numismatic Society: Washington.

Kikta, S. (1980). Filateliya. In: Entsyklopediya ukrayinoznavstva, Vol. 9: EU-II. Paris-New York: Molode Zhyttya: 3498-3505. (In Ukrainian)

fig. 6. Postage stamps of Ukraine "90th anniversary of postage stamps of the Ukrainian People's Republic "Viennese issue" 2010-2011

\section{Conclusions}

Thus, the aesthetic criteria of UNR postage stamps, production and quality of their performance have become important features for modern national design in the context of world samples. In particular, the embodiment of artistic image in contemporary graphic design is a reflection of reality through artistic means. All the elements combined in the complex structure of postal miniature of Ukraine indicate its national benchmarks created with the use of techniques and symbols elaborated by the national masters of Ukraine.

Moreover, a postage stamp is not just an art miniature, it is a kind of matrix that has the ability to link history as a historiographic text with a narrative reconstruction of the past.
Kramarenko, M. (2011). Ukraina. Katalog pochtovykh marok 18662010. Donetsk: Novyy mir. (In Russian)

Kuzych, I. (2004). Introductory Handbook of Ukrainian Philately. Philatelic and Numismatic Society: Springfield.

Levitas, Y. (1991). I seryezno, i kuryezno. Moscow: Radio i sviaz. (In Russian)

Levítas, Y., Basyuk, V. (1975). Vse pro marki. Kiev: Reklama. (In Russian)

Maksymchuk, Yu. (1996). Proektovani, ale ne vydani marky UNR (1956 "My i svit"). Lviv. Halfilvisnyk. 4(12). (In Ukrainian)

Redko, O. (2017). "...Bazhayu ... Dochekatysya vyzvolennya Ukrayiny..." (ohlyad dokumentiv TSDAVO Ukrayiny pro diyalnist ukrayinskoho hromadskoho i kulturno-osvitnioho diyacha YE. S. Vyrovoho). Ohlyady dzherel ta dokumentalni rysy. Issue 3-4, pp. 178-192. Retrieved from https://archives.gov.ua/Publicat/AU/AU_3_2017/AU-3-4_2017_178s-192s.pdf. 
Roberts, C. and Seichter, R. (1989). The Trident Issues of Ukraine. Part I-V. UPNS Special Publication № 1. Ukrainian Philatelic and Numismatic Society: Washington.

Seichter, R. (1966). Sonder-Katalog Ukraine 1918/20. Soltau: Union der Philatelisten der Ukraine.

Seichter, R. und Teuber, W. (1942). Gesamtliste der Briefmarken der Ukraine. Hamburger: Union der Philatelisten der Ukraine.

Shramchenko, S. (1996). Ukrayinska derzhavna poshtova marka za 20 hryven z 1918 roku (1952 Ukrayinskyy filatelist). Lviv: Halfilvisnyk. Issue 4 (12). (In Ukrainian)

Zeichter, R. (2003). 45 rokiv ukrayinskym markam [transl. from german]. Filateliya Ukrayiny. No 43: 10-12. (In Ukrainian)

\section{LIST OF REFERENCES LINKS}

Бехтір В. Каталог поштових марок України. Київ: Українське державне підприємство поштового зв'язку "Укрпошта", 1997.

Білокінь С. Георгій Нарбут і українська поштова марка. Поuта і фрілателія України. 1996. Вип. № 1. 19.

Бишкевич Р. Начерк історії української філателії. Класичний період. Львів. Спеціальний випуск часопису "Галфілвісник". 2004.

Гонцарюк І., Рипела Д. Каталог поштових марок (1918-2017) Братислава: DIVARI, 2017.

Граллерт В., Грушке В. Филателистический словарь / сокр пер. с нем. Ю. М. Соколовой и Е. П. Сашкеновой. Москва: Связь, 1977

Зайхтер Р. 45 років українським маркам / пер. з нім. В. Мартинюка, А. Бранделіса. Філателія України. 2003. № 43 C. 10-12.

Кікта С. Філателія. Енциклопедія українознавства. Т. 9: ЕУ-ІІ. Париж, Нью-Йорк: Молоде Життя, 1980. С. 3498-3505.

Крамаренко М. Украина. Каталог почтовых марок 1866-2010. Донецк: Новый мир, 2011.

Левитас Й. И серьезно, и курьезно. Москва: Радио и связь, 1991.

Левітас Й., Басюк В. Все про марки. Київ: Реклама, 1975.

Максимчук Ю. Проектовані, але не видані марки УНР (1956 "Ми і світ"). Львів. Галфілвісник. 1996. Вип. 4 (12)
РеДьКО О. 2017 "...БАЖАЮ ... ДОЧЕКАТИСЯ ВИЗВОЛЕННЯ УКРАЇНИ..." (огляд документів ЦДАВО України про діяльність українського громадського і культурно-освітнього діяча Є. С. Вирового). Оәляди джерел та документальні риси. вип. 3-4, стаття 178-192. URL : https://archives.gov.ua/ Publicat/AU/AU_3_2017/AU-3-4_2017_178s-192s.pdf.

Chinburg Ziven K. Halting the Revolution: Poland and the "Miracle at the Vistula". Constructing the Past. 2015. Vol. 16: Iss. 1, Article 4. Retrieved from https://digitalcommons.iwu.edu/ constructing/vol16/iss $1 / 4$

Фурман В. Общегосударственные стандартные почтовые марки Украины. Киев: Марка України, 2003.

Фурман В. Привабливості "Попелюшки". Філателія України. 2005. № 4 (54). С. 6-8.

Чигринець А. Поштові марки України. Історія, опис, класифікація (1948 Брюссель). Львів. Галфілвісник. 1994. Вип. 1.

Чучин Ф. Каталог почтовых марок и цельных вещей. Выпуск IV. Украина. Москва: Советская филателистическая ассоциация, 1927.

Шрамченко С. Українська державна поштова марка за 20 гривень з 1918 року (1952 Український фрілателіст). Львів. Галфрілвісник. 1996. Вип. 4 (12)

Arnold A. Aufdruck-Tabelle der Ukraine-Provisorien. Berlin Wilmersdorf, 1919

Bulat J. Illustrated Postage Stamp History of Western Ukrainian Republic 1918-1919. Yonkers: Philatelic Publications, 1973.

Bulat J. Comprehensive Catalogue of Ukrainian Philately. Yonkers: Philatelic Publications, 2003.

Hennig K. Ukraine. Weimar, 1920.

Hugel L. Postal Usage of Stamps Issued in Ukrain: 1918-1919. Ukrainian Philatelic and Numismatic Society: Washington, 1988.

Kuzych I. Introductory Handbook of Ukrainian Philately. Philatelic and Numismatic Society: Springfield, 2004

Roberts C. and Seichter R. The Trident Issues of Ukraine. Part I-V. UPNS Special Publication № 1. Ukrainian Philatelic and Numismatic Society: Washington, 1989.

Seichter R. und Teuber W. Gesamtliste der Briefmarken der Ukraine. Hamburger: Union der Philatelisten der Ukraine, 1942.

Seichter R. Sonder-Katalog Ukraine 1918/20. Soltau: Union der Philatelisten der Ukraine, 1966.

\section{Світлана Орехова,}

Маріупольський державний університет (м. Маріуполь, Україна)

e-mail: sv.orehova@ukr.net, OCRID 0000-0001-9303-4469

\section{УКРӒ̈НСЬКЕ ПОШТІВНИЦТВО ЗА ЧАСИ ВИЗВОЛЬНИХ ЗМАГАНЬ 1918-1920 рр.: ІСТОРИЧНИЙ НАРАТИВ НАЦІОНАЛЬНОГО МАРКОВИДАННЯ}

Статтю присвячено реконструкції національних історичних наративів у світлі національного поштового марковидання в Україні. Дослідження ґрунтується на вивченні зображального контенту поштових марок Української Народної Республіки 1918-1920 рр. як вираження державної політики на шляху розвитку національної поштової служби, яка відігравала важливу роль у процесі державотворення. Метод діахронного аналізу дає можливість дослідити процес трансформації статусу поштових марок від фрілателістичного матеріалу до стану культурно-історичної пам'ятки. Аналітичне вивчення каталогізованих поштових марок 3 загальним наративом минулого державної поштової структури Української Народної Республіки визначається як українська філателістична спадщина. Робиться висновок, що поштові марки, як елемент державності України першої половині XX ст.,у сучасному наративі історичної пам'яті сформували основи сучасного національного марковидання.

Ключові слова: історична пам'ять; марковидання; наратив; поштова марка; провізорії; фрілателістична спадщина.

(C) Svetlana Oriekhova

Надійшла до редакції: 28.10.2019

Прийнята до друку: 15.11.2019 